\title{
Report from the International Conference "Public policy amid the COVID-19 pandemic. Analysis of the problem and challenges for the future", Szczecin, 9 June 2021
}

\section{Małgorzata Kamola-Cieślik}

\author{
DOI: https://doi.org/10.15804/rop2021313
}

On 9 June 2021 the international scientific conference on "public policy amid the COVID-19 pandemic. Analysis of the problem and challenges for the future" took place. It was organized by the Department of Political Systems and Public Policy of the Institute of Political Science and Security of the University of Szczecin and the Szczecin Branch of the Polish Political Science Association. Due to the epidemiological situation in Poland and in the world, the conference took place online using the Microsoft Teams platform. Honorary patronage over the conference was taken by the Governor of Zachodniopomorskie Province, Zbigniew Bogucki, the Marshal of Zachodniopomorskie Province, Olgierd Geblewicz, and the Mayor of Szczecin, Piotr Krzystek.

The function of the Chairperson of the conference's Scientific Board was held by His Magnificence, the Rector of the University of Szczecin, Prof. dr hab. Waldemar Tarczyński. The conference's Scientific Board was composed of prominent scien- tists from Poland and abroad: Prof. dr hab. Nezir Akyesilmen (Selcuk University), Prof. dr hab. Oleg Bazaluk (Guangdong University of Petrochemical Technology), Prof. dr hab. Marek Ćwiklicki (Cracow University of Economics), Prof. US dr hab. Kinga Flaga-Gieruszyńska (University of Szczecin), Prof. US dr hab. Krzysztof Kowalczyk (University of Szczecin), Prof. UMK dr hab. Jacek Knopek (Nicolaus Copernicus University in Toruń), Prof. UEP dr hab. Ida Musiałkowska (Poznań University of Economics and Business), Prof. dr hab. Bilal Sambur (Ankara Yildirim Beyazit University), Prof. dr hab. Denys Svyrydenko (Guangdong University of Petrochemical Technology), Prof. dr hab. Benon Z. Szałek (University of Szczecin), Prof. dr hab. Tadeusz Wallas (Adam Mickiewicz University in Poznań), Prof. dr hab. Elżbieta Załoga (University of Szczecin), Prof. dr hab. Andrzej Zybała (SGH Warsaw School of Economics), and Prof. UWr dr hab. Przemysław Żukiewicz (University of Wrocław). 
The conference was made possible by the work and engagement of the Organization Committee made up of: Prof. US dr hab. Małgorzata Kamola-Cieślik (Chairperson), dr Dorota Rdzanek (ViceChairperson), dr Marta Szulc (Secretary), dr hab. Agnieszka Lipska-Sondecka, and dr Liana Hurska-Kowalczyk.

The conference was the first in the cycle of annual scientific meetings devoted to public policy, which remains a research subject of many scientific fields. The theme of the conference was determined by the outcomes of the global COVID-19 pandemic, which began at the beginning of 2020 and exerted an adverse impact on people, society and the economy. State and local governments of most countries have faced the new challenge of building a new action coordination system and developing effective tools to tackle the pandemic. The aim of the conference was to give the participants a platform for sharing views, experiences and findings concerning the efficient management of public policy both during and after the COVID-19 pandemic.

The conference was officially inaugurated by the Director of the Institute of Political Science and Security of the University of Szczecin, dr hab. Tomasz Czapiewski, and the Prorector for Education of the University of Szczecin and Head of the Szczecin Branch of the Polish Political Science Association, prof. US dr hab. Renata Podgórzańska. The Director of the Institute of Political Science and
Security of the University of Szczecin, dr hab. Tomasz Czapiewski, welcomed all the attendees and guests and the Prorector for Education of the University of Szczecin, prof US dr hab. Renata Podgórzańska, wished fruitful deliberations and meaningful findings to all the participants.

The Szczecin conference was attended by over 60 people representing various academic and research centres in the country and abroad. They were the representatives of different scientific fields: political and administrative science, economics and finance, management and quality science, legal science, security sciences, sociology, and pedagogy.

The conference started with a plenary session, which was divided into two parts. During the first part, moderated by dr. hab. Tomasz Czapiewski, speeches were delivered by: prof. UEP dr hab. Ida Musiałkowska, prof. dr hab. Andrzej Zybała, and prof. UWr dr hab. Przemysław Zukiewicz. The first person to take the floor was prof. dr hab. Andrzej Zybała who focused on challenges to knowledge and evidence-based policy during the pandemic. He presented a methodological approach to the research on public policy. The next speaker, prof. UWr dr hab. Przemysław Żukiewicz, addressed the issues related to the network and cross-sectoral nature of public policy during the COVID-19 pandemic and the challenges that political leaders will face in the post-pandemic period. Professor 
Żukiewicz compared the prospective and reactive approach to public management in times of crisis based on specific examples. On the other hand, prof. UEP dr hab. Ida Musiałkowska stressed that the COVID-19 pandemic has had a significant impact on public policy in various areas. Therefore, the changes resulting from the pandemic crisis demand and will demand implementing new measures in the legislative process and identifying new sources of financing for political decisions. Professor Musiałkowska talked about the application of (meta) financial instruments of the European Union's policy in the post-pandemic period. Once the speeches ended, the discussion began which was summarized by dr hab. Tomasz Czapiewski.

During the second part of the plenary session, moderated by dr. hab. Andrzej Zybała, the first person to take the floor was prof. dr hab. Benon Z. Szałek from the University of Szczecin who presented a number of praxeological reflections on public policy, inter alia, in the context of various ways of defining this term. On the other hand, prof. dr hab. Jacek Sroka from the Pedagogical University of Krakow referred to the principles of functioning of the participatory budgeting amid the COVID-19 pandemic and barriers to deliberative formulas. The next speeches were delivered by prof. SWPS dr hab. Karol Olejniczak, prof. SWPS dr hab. Igor Lyubashenko, and dr Katarzyna
Wojtkiewicz from the SWPS University in Warsaw. The speakers drew attention to the challenges faced by public policy in a crisis, including the issues related to cross-sectoral liaison and low effectiveness of policy instruments. They believe that in a crisis situation it will be necessary to design public policy taking into account two goals - striving for theoretical and methodological excellence and creating practical tools allowing societies to better tackle the problems of the pandemic crisis. Then, the participants heard the speech delivered by prof. UJK dr hab. Marek Leszczyński from Jan Kochanowski University in Kielce who brought attention to the fact that the crucial task of state and local-level public institutions during the pandemic is to assure the social security. The last speech in this part of the session was given by dr Marcin Kędzierski from the Cracow University of Economics presenting the main theses of the report of the Centre for Public Policy of the Cracow University of Economics People's improvisations. How is the pandemic changing social norms? which he co-authored. After listening to all the speakers, the participants held a discussion.

Further deliberations were divided into six thematic panels: Migration processes in the context of public policy during the pandemic (moderated by prof. US dr hab. Renata Podgórzańska), Social policy and fighting the COVID-19 pandemic (moderated by prof. US dr hab. Małgorzata 
Kamola-Cieślik), Human rights during the era of COVID-19 Pandemic (moderated by dr Mateusz Smolaga), Tasks and actions of state and local governments amid the COVID-19 pandemic (moderated by prof. US dr hab. Krzysztof Kowalczyk), Selected sectoral policies during the COVID-19 pandemic (moderated by prof. UEP dr hab. Ida Musiałkowska), Student panel (moderated by dr Liana Hurska-Kowalczyk). Each thematic panel involved speeches and a discussion providing the participants with a platform to exchange their views, comments and opinions on their research.
When summing up the deliberations, the Director of the Institute of Political Science and Security of the University of Szczecin, dr hab. Tomasz Czapiewski, referred to them as fruitful and satisfying. While expressing his gratitude to the participants of the conference, he invited them to participate in the second in the cycle of scientific conferences devoted to public policy, which will be held in June 2022 in Szczecin. With that the conference ended.

Szczecin, 10 July 2021 Małgorzata Kamola-Cieślik 